\title{
Budaya Lisan sebagai “Pembawa Nilai Normatif” Masyarakat Santri : Analisis Konten Didaktik dan Penyusunan Cergam Legenda Para Ulama
}

\author{
Oral Culture as a Santri's "carrier of norms" : \\ Analysis of Didactic Content and Arranging Pictorial Stories \\ of The Legend of Ulama
}

\author{
M. Bayu Firmansyah,S.S.,M.Pd. \\ Tristan Rokhmawan,S.S.,M.Pd \\ STKIP PGRI Pasuruan
}

Penelitian ini berhasil menemukan, menganalisis, dan menyusun ulang cerita legenda Kiai di Kota Pasuruan. Peneliti mengumpulkan berbagai cerita terkait Kiai dengan fokus penelusuran pada cerita yang bernilai didaktik. Peneliti mendatangi delapan situs penleitian berupa makam Kiai. Peneliti mendapatkan sepuluh judul cerita bermuatan konten didaktik. Selanjutnya untuk membuktikan bahwa cerita-cerita yang dikumpulkan memiliki muatan konten didaktik, peneliti menganalisis isi cerita dengan pendekatan analisis konten. Analisis konten dilakukan untuk membuktikan keberadaan konten didaktik berupa penggambaran nilai baik-buruk, moral, dan sanksi. Dari hasil analisis ditemukan bahwa cerita legenda Kiai dalam budaya lisan masyarakat santri Kota Pasuruan memuat konten didaktik terkait nilainilai normatif dalam masyarakat. Pandangan hidup masyarakat santri mengenai nilai baik-buruk, moral, dan sanksi dicerimkan dalam isi legenda Kiai untuk diteruskan sebagai pesan bagi anak-anak, generasi penerus mereka. Budaya lisan berupa cerita legenda Kiai ini telah menjadi "pembawa nilai normatif" yang menjadi karakteristik kearifan masyarakat santri. Sebagai produk akhir penelitian, peneliti melakukan penelitian pengembangan dengan pendekatan metode 4D (define, design, develope, and disseminate) untuk membukukan cerita legenda Kiai dalam bentuk cerita bergambar/ cergam bergenre cerita anak. Penyusunan cergam legenda Kiai bergenre cerita anak disusun dengan mengikuti karakteristik sastra anak dan dikemas dengan desain yang cocok untuk anak-anak.

Kata kunci : nilai normatif, santri, legenda Kiai, konten didaktik, cerita bergambar

This research has found, analyzed, and rearranged the story of Kiai in Pasuruan City. The researchers collected various legends of Kiai with a search focus on a doactic story. Researchers visited eight research sites. the site is Kiai's grave. Researchers get ten titles of the story containing didactic content. Furthermore to prove that the stories collected have the content of didactic content, the researcher analyzes the content of the story with a content analysis approach. Content analysis is performed to prove the existence of didactic content in the form of depictions of good grades, morals, and sanctions. The results of the analysis found that the story of Kiai in oral culture of santri 
community of Pasuruan City contains didactic content related to normative values in society. The view of the santri community's living on good-bad, moral, and sanctioned values is contained in the contents of Kiai's legend to be continued as a message for children, their future generations. The oral culture of Kiai legend has become the "carrier of norms" which characterizes the wisdom of the santri community. As the final product of research, researcher do development research with approach of 4D method (define, design, develope, and disseminate) to record Kiai legend in the form of pictorial stories of children story genre. This pictorial stories are arranged by following the characteristics of children's literature and are packed with designs suitable for children.

Keyword : normative values, santri, kiai's legend, didactic content, pictorial stories

Indonesia adalah negeri yang kaya akan budaya lisan. Budaya ini menyebar di berbagai daerah di seluruh penjuru nusantara (Dananjaja,1994). Sebelum mengenal budaya aksara (writing culture) semua bangsa di dunia hidup dalam budaya lisan (oral culture). Salah satu wujud budaya lisan itu adalah prosa naratif lisan yang banyak beredar dalam kehidupan masyarakat. Salah satu prosa naratif lisan masyarakat yang sering dikaji adalah legenda. Legenda yang dituturkan secara lisan tergolong dalam bentuk folklore lisan, istilah yang pertama kali diperkenalkan oleh William John Thoms (1846), seorang ahli benda-benda dan antropoligi kuno Inggris. Secara terminologis folklore bermakna kultur tradisional (lore) yang dutunjukkan / dituturkan rakyat / orang-orang (folk). Dengan begitu folklore lisan dapat diartikan sebagai sebuah kultur tradisional lisan yang dituturkan oleh masyarakat pada suatu tempat. Dundes dalam Dananjaja (2002) mendefinisikan folk adalah sekelompok orang yang memiliki ciri-ciri pengenal fisik, sosial dan kebudayaan sehingga dapat dibedakan dengan kelompok-kelompok lainnya. Istilah lore merupakan tradisi folk yang berarti sebagian kebudayaan yang diwariskan secara turuntemurun, secara lisan, atau melalui contoh yang disertai gerak isyarat atau alat bantu mengingat. Jika folk adalah mengingat, lore adalah tradisinya.

Foklor lisan adalah foklor yang bentuknya memang murni lisan. Bentuk-bentuk foklor yang termasuk ke dalam kelompok besar ini antara lain (a) bahasa rakyat seperti logat, julukan, pangkat trandisional, dan title kebangsawanan, (b) ungkapan tradisional seperti peribahasa, pepatah, dan pameo, (c) pertanyaan tradisional seperti tekateki, (d) puisi rakyat, seperti pantun, gurindam dan syair, (e) cerita prosa rakyat, seperti: mite, legenda, dan dongeng, dan (f) nyanyian rakyat (Dananjaja, 2002). Dalam tulisan ini, legenda Kiai Sepuh 
digolongkan dalam bentuk cerita prosa rakyat. Beberapa rujukan lain menyebutnya pula dengan prosa naratif lisan.

Dari semua jenis folklor lisan, cerita rakyat (dalam bentuk prosa naratif lisan) adalah yang paling banyak mendapat perhatian dari para peneliti sastra lisan. Sebagaimana ciri-ciri yang dimiliki oleh jenis sastra lisan, cerita-cerita lisan ini bersifat anonim. Dalam perkembangan dan penuturannya, cerita rakyat cenderung menjadi milik kolektif dalam sebuah kelompok masyarakat. William R.Bascom, membagi cerita prosa rakyat atau prosa naratif lisan dalam tiga golongan besar, yaitu : 1) mite, 2) legenda, dan 3) dongeng (Bascom, 1965; Dananjaja, 2002).

Sebagai bagian dari hasil kebudayaan dalam sebuah kolektif masyarakat, setiap kolektif pasti memiliki sastra lisannya sendiri, termasuk pula masyarakat Pasuruan. Pasuruan sebagai masyarakat yang dikenal dengan simbol 'Kota Santri' adalah kota yang banyak memiliki tokoh pemuka agama, hingga kota Pasuruan juga seringkali dijuluki sebagai kotanya aulia (kota milik para ulama). Fenomena sosial ini, bila kita cermati dari sisi penciptaan hasil budaya sastra lisan, banyak mempengaruhi tumbuh suburnya sastra lisan yang berkaitan dengan legenda-legenda para ulama.

Budaya lisan mampu menciptakan citra khas sebuah kebudayaan lokal. Budaya lisan berlaku sebagai bentuk karya sastra yang dibangun dalam tuturan kolektif masyarakat tertentu. Seluruh unsur cerita, tema dan pesan di dalamnya, tidak terlepas dari karakter masyarakat yang menciptakan. Masyarakat layaknya pengarang yang mengungkapkan pandangannya terhadap dunia dalam sebuah karangan. Meminjam konsep strukturalisme genetik dalam proses perwujudan karya sastra oleh pengarang, penulis meyakini bahwa masyarakat juga banyak mencurahkan pandangannya tentang dunia melalui usaha perwujudan bentuk-bentuk tradisi lisan. Strukturalisme genetik memasukan faktor genetik dalam karya sastra, genetik sastra artinya asal usul karya sastra. Adapun faktor yang terkait dalam asal muasal karya sastra adalah pengarang dan kenyataan sejarah yang turut mengkondisikan saat karya sastra itu diciptakan (Faruk, 2014).

Sastra lisan merupakan ekspresi lisan sebuah komunitas budaya suatu kelompok masyarakat atau kolektif yang tersebar di berbagai kelompok suku bangsa yang beragam, maka konten dalam cerita lisan pun berbeda-beda sesuai dengan karakteristik dan kepribadian masyarakat penuturnya. Dalam masyarakat dengan latar budaya santri, narasi lisan yang bertema keagamaan dan cerita seputar tokoh-tokoh agama berkembang dengan subur. Kontennya sangat khas, masyarakat santri atau pesantren mengembangkan sastra lisan 
dengan konten ajaran agama dan norma baik-buruk yang berlaku secara umum dalam masyarakat pesantren.

Dalam kajian sebelumnya, penulis mengemukakan bahwa legenda rakyat bertajuk Kiai Sepuh yang berkembang di Kota Pasuruan mencerminkan kepercayaan irasional yang berkembang dalam imajinasi kolektif masyarakat penuturnya. Lebih dari sekadar memuat pandangan kolektif masyarakat, budaya lisan berfungsi pula sebagai sarana didaktif bagi masyarakat untuk mengajarkan nilai-nilai baik yang mereka kembangkan (Rokhmawan \& Firmansyah,2015). Norma-norma kehidupan yang dimuat dalam cerita lisan adalah cermin pandangan masyarakat kolektif tentang nilai baik-benar yang harus ajarkan pada generasi penerusnya.

Legenda Kiai di Kota Pasuruan banyak dibacakan dalam acara-acara peringatan agama Islam seperti pada hari-hari besar Islam, mauludan (maulid Nabi Muhammad SAW), ataupun haul (peringatan meninggal) Kiai yang dirangkum dalam lembaran-lembaran manakib (rangkuman sejarah perjalanan dan biografi seorang ulama). Selain itu, legenda Kiai juga banyak berkembang dan hidup dalam masyarakat melalui penuturan lisan. Secara luas legenda Kiai diceritakan dalam kegiatan mengaji atau melalui tuturan orang-orang tua pada anak-anak di lingkup desa (Rokhmawan \& Firmansyah,2015).

Melalui pendekatan analisis konten, penulis ingin mendalami konten didaktik dalam penuturan prosa-naratif lisan yang dituturkan dalam budaya lisan masyarakat Kota Pasuruan. Untuk membatasi cakupan penelitian, peneliti membatasi kajian pada cerita-cerita tentang ulama diKota Pasuruan. Penulis tertarik untuk menjabarkan berbagai bentuk pesan normatif yang ada dalam cerita dan menegaskannya sebagai bentuk pandangan hidup kolektif masyarakat kota pasuruan. Dengan bukti inilah penulis dapat mengungkapkan pentingnya membawa konten budaya lisan ini ke dalam lingkungan dunia pendidikan.

Konten didaktik yang dimaksud adalah bentuk-bentuk pandangan kolektif masyarakat mengenai nilai, norma, dan sanksi yang patut diajarkan untuk mengendalikan pranata sosial. Nilai pada dasarnya disebut sebagai standar penuntun dalam menentukan sesuatu itu baik, indah, berharga atau tidak (Fraenkel, dalam Soenarjati \& Cholisin, 1989). Secara aksiologis, nilai itu dibagi macamnya menurut kualitas nilainya, yaitu ke dalam nilai baik dan buruk yang dipelajari oleh etika, dan nilai indah dan tidak indah yang dipelajari oleh estetika. Norma adalah petunjuk tingkah laku yang harus dilakukan dan tidak boleh dilakukan dalam hidup sehari-hari, berdasarkan suatu alasan (motivasi) tertentu dengan disertai sanksi. Sanksi adalah ancaman/akibat yang akan diterima apabila norma tidak dilakukan (Widjaja, 1985: 168). Dalam kehidupan umat manusia terdapat bermacam-macam norma, yaitu norma agama, 
norma kesusilaan, norma kesopanan, norma hukum dan lain-lain. Norma agama, norma kesusilaan, norma kesopanan, dan norma hukum digolongkan sebagai norma umum. Selain itu dikenal juga adanya norma khusus, seperti aturan permainan, tata tertib sekolah, tata tertib pengunjung tempat bersejarah dan lain-lain. Sanksi diberikan ketika nilai baik dan norma yang dituntut tidak dipenuhi oleh seorang anggota masyarakat. Begitulah terminologi nilai, norma, dan sanksi. Ketiganya mempunyai hubungan yang erat, terutama dalam wacana pendidikan moral, pembentukan sikap-sikap, pembangunan watak bangsa (the character building) dan sebagainya.

Lebih dari tujuan analisis konten didaktik, tujuan utama penulisan artikel dan pelaksanaan penelitian budaya lisan ini adalah untuk menginventarisir prosa naratif lisan tentang kiai ini dalam bentuk tulis. Penulis berpendapat bahwa inilah tujuan utama dalam segala usaha penelusuran folklore lisan. Karena berkembang hanya secara lisan dan hanya dilisankan oleh beberapa orang yang terkait dengan keluarga kiai atau masyarakat asli, legenda Kiai lambat laun akan punah jika tidak terus diceritakan. Perpindahan masyarakat, masuknya pendatang dari daerah lain, dan hilangnya penutur-penutur asli karena meninggal atau pindah ke daerah lain akan semakin mendesak keberadaan legenda ini. Oleh karenanya, mentranskripsikan cerita lisan dalam bentuk tulisan untuk menjaga kelestarian cerita lisan adalah tugas utama pada penelitian folklore dan cerita lisan. Produk akhir penelitian ini adalah analisis konten didaktik dan penyusunan cergam bertajuk cerita legenda Kiai.

Dengan berbagai fakta dan permasalahan di atas, penulis merasa perlu untuk meneliti, mentranskripkan dalam bentuk tulis, dan menginterpretasi cerita legenda Kiai Sepuh. Tujuannya jelas agar cerita ini dapat terus lestari, dikenal, dan dapat dipahami maknanya oleh masyarakat umum. Di samping itu juga bertujuan keilmuan untuk mengembangkan kajian folklore lisan khususnya dalam bentuk folklore naratif atau cerita lisan. Melalui artikel ini, penulis menyampaikan hasil penelitiannya terhadap 1) bentuk cerita legenda Kiai, 2) bentukbentuk nilai didaktik yang tercermin melalui isi cerita legenda Kiai, dan 3) penyusunan cergam legenda Kiai.

\section{METODE}

Peneliti mendekati konten legenda Kiai di Kota Pasuruan dengan pendekatan analisis konten (content analysis). Pendekatan ini memungkinkan peneliti untuk memahami legenda sebagai sebuah rangkaian sistematis yang dapat dianalisis untuk menemukan unit-unit pembentuk cerita / struktur dan kemudian menginterpretasi konten di dalamnya. Pada akhirnya, peneliti dapat menerjemahkan setiap konten didaktik berupa pesan normatif dan 
ajaran agama di dalam prosa naratif lisan bertajuk Kiai yang dituturkan masyarakat Kota Pasuruan. Selanjutnya dalam mengembangkan susunan cergam legenda Kiai, peliti menggunakan pendekatan berbasis proyek penelitian dan pengembangan / R\&D.

Untuk mencapai tujuan-tujuan penelitian, tiga langkah penelitian yang diterapkan dalam penelitian ini. Pertama, tahap pengumpulan data teks lisan naratif legenda-legenda Kiai di Kota Pasuruan. Kedua, tahap analisis isi terhadap fokus interpretasi konten didaktik berupa pesan normatif dan ajaran agama pada teks yang telah ditranskripsi dalam bentuk naskah tertulis. Kedua langkah penelitian dilakukan dengan dasar metode penelitian etnografi. Metode ini dilakukan dengan runtutan teknik pengumpulan data berupa observasi partisipasi, wawancara terbuka-mendalam, dan studi pustaka (untuk tujuan memahami dan menafsirkan objek penelitian secara intrinsik dan ekstrinsik). Metode etnografi dimanfaatkan untuk membangun suatu pengertian yang sistematik mengenai kebudayaan manusia dari perspektif orang yang telah mengalami atau mempelajari kebudayaan tersebut. Selain itu, metode etnografi digunakan sebagai upaya untuk menemukan bagaimana masyarakat setempat mengorganisasikan budaya mereka dalam pikiran mereka dan kemudian menggunakan budaya tersebut dalam kehidupan (Spradley, 1997). Ketiga, peneliti mengembangkan hasil penelitian dalam wujud cergam / cerita bergambar bertajuk legenda Kiai. Untuk melaksanakan tahap ini peneliti menggunakan empat tahap penelitian dan pengembangan 4D : define, design, develope, and disseminate (Thiagarajan, Semmel, \& Semmel, 1974).

Dalam pengumpulan data teks lisan naratif legenda Kiai Sepuh, penulis melakukan rangkaian metode perekaman dan transkripsi sastra lisan dalam bentuk tulis. Penulis sebagai peneliti mengumpulkan data cerita lisan legenda Kiai Sepuh dengan 11 langkah : 1) menetapkan cerita legenda Kiai Sepuh sebagai objek perekaman dan transkripsi, 2) menetapkan situs petilasan (makam) Kiai Sepuh sebagai pusat pencarian, 3) menentukan batas wilayah pencarian dengan menarik garis $1 \mathrm{~km}$ melingkari situs sebagai pusat pencarian, 4) menetapkan narasumber dengan ketentuan usia diatas 50 tahun, warga asli / kelahiran desa Gentong, dan tidak pindah domisili atau menetap dalam kurun waktu hidupnya, 5) melakukan wawancara dengan narasumber, 6) merekam proses wawancara dalam bentuk video / rekam suara, 7) mentranskripsikan hasil wawancara lisan dalam bentuk tulisan, 8) mentransliterasikan beberapa bagian cerita, 9) menginventarisir cerita-cerita berikut variasi cerita yang serupa, 10) membandingkan dan menyelaraskan isi cerita dari setiap narasumber yang telah diinventarisir untuk menemukan runtut cerita yang berlaku dan diakui secara umum, dan 11) menyusun ulang / menyunting teks. 
Pengumpulan data teks lisan naratif legenda Kiai Sepuh dilakukan dalam kurun waktu 6 minggu. Jumlah narasumber terbagi dalam narasumber utama dan sumber tambahan. Narasumber utama berfungsi sebagai sumber utama cerita. Narasumber ini dipilih berdasarkan kedekatannya dengan area situs. Sumber tambahan mendukung informasi dari narasumber utama misalnya dalam bentuk naskah. Semua narasumber utama berusia di atas 50 tahun dan lahir dan tinggal / berdomisili di sekitar situs hingga penelitian dilakukan.

Dalam analisis isi terhadap konten didaktik, penulis melakukan rangkaian metode interpretasi isi teks. Penulis sebagai peneliti menginterpretasi isi teks untuk menemukan bentuk-bentuk konten didaktik mencakup nilai, norma umum, dan sanksi yakni : 1) nilai baik, 2) nilai buruk, 3) norma agama, 4) norma kesusilaan, 5) norma kesopanan, 6) norma hukum, dan 7) sanksi. Produk akhir dikembangkan dalam bentuk cergam (cerita bergambar). Setelah dilakukan penetapan subjek tokoh, latar dan konten cerita, peneliti mendesain bentuk cergam.

\section{HASIL DAN PEMBAHASAN}

\section{Legenda Kiai}

Legenda adalah jenis prosa naratif yang mirip dengan mitos. Legenda diperlakukan sebagai suatu kebenaran atau suatu kejadian yang sungguh-sungguh pernah terjadi oleh 'si empunya cerita' dan pendengarnya. Namun mereka diposisikan dalam sebuah periode yang lemah akan pertimbangan. Legenda seringkali lebih bersifat sekuler (duniawi) daripada menunjukkan kekeramatan, namun tidak menutup pula kemungkinan adanya beberapa legenda yang menunjukkan kekeramatan atas sesuatu yang memiliki kekuatan magis. Karakter utama legenda pada umumnya adalah manusia. Legenda seringkali menceritakan tengang migrasi, perang dan kemenangan, perbuatan seseorang atau pahlawan di masa lampau, seorang tokoh masyarakat, dan raja-raja, dan kesuksesan mereka dalam mengatur sebuah dinasti. Dalam hal ini pencerita dan pendengarnya seringkali menyesuaikan dengan tradisi verbal dalam sejarah tertulis. Oleh karenanya legenda seringali juga dipandang sebagai 'sejarah' kolektif (folk history), walaupun 'sejarah' itu karena tidak tertulis telah mengalami distorsi, sehingga seringkali dapat jauh berbeda dengan kisah aslinya. Hal ini dikarenakan selain sejarah nyata, legenda juga memasukkan unsur-unsur kisah lokal seperti harta terpendam, hantu, peri, dan orang-orang suci. Melalui bagian inilah unsur magis, kekeramatan dan kepercayaan irasional masuk dalam cerita legenda. Lebih lanjut, secara rinngkas legenda adalah cerita-cerita pada zaman dahulu yang bertalian dengan peristiwa- 
peristiwa sejarah. Legenda adalah cerita rakyat tentang tokoh, peristiwa, atau tempat tertentu yang mencampurkan fakta historis dan mitos / kepercayaan irasional (Dananjaja, 2002 ; Bascom, 1965 ; Panuti sudjiman dalam Lantini, 1996). Legenda termasuk salah satu bentuk folklore yang disebut cerita rakyat. Cerita biasanya dihubungkan dengan peristiwa dan benda yang berasal dari masa lalu, seperti peristiwa penyebaran agama Islam atau peristiwa lain yang terjadi di masa lalu. Para pelaku digambarkan sebagai pelaku yang benar-benar pernah hidup di masa lalu. mereka orang terkemuka, yaitu tokoh yang membangun kesejahteran masyarakatnya. Latar cerita legenda berupa tempat yang dapat diidentifiasi secara geografis. Dalam kajian folklore, Danandjaja mengemukakan legenda sebagai prosa cerita rakyat yang dianggap benar-benar terjadi engan tokoh-tokoh orang yang luar biasa (keramat) yang terjadi di masa lampau (Dananjaja, 2002). Legenda seringkali dirancukan dengan mith (mite) dan folktale (dongeng). Ketiganya berbeda dalam bentuk dan isinya. Perbedaan tersebut dapat dilihat dalam tabel yang telah disusun oleh Bascom berikut (Bascom, 1965)

\begin{tabular}{|c|c|c|c|c|}
\hline 1 & Jenis & Mite & Legenda & Dongeng \\
\hline 2 & Karangan & \multicolumn{3}{|c|}{ Prosa Naratif Lama } \\
\hline 3 & Pembuka konvensional & \multicolumn{2}{|c|}{ Tidak ada } & Pada umumnya ada \\
\hline 4 & $\begin{array}{l}\text { Dibacakan malam hari / } \\
\text { cerita pengantar tidur }\end{array}$ & \multicolumn{2}{|c|}{ Tidak harus / dibiasakan } & Pada umumnya ya \\
\hline \multirow[t]{3}{*}{5} & Setting & \multicolumn{2}{|c|}{ Terikat waktu dan tempat tertentu } & $\begin{array}{c}\text { Tidak terikat waktu dan } \\
\text { tempat tertentu }\end{array}$ \\
\hline & Waktu & Sangat jauh lampau & $\begin{array}{c}\text { Relatif tidak terlalu } \\
\text { lampau }\end{array}$ & Tidak terikat waktu \\
\hline & Tempat & $\begin{array}{c}\text { Menyangkut pula } \\
\text { tempat-tempat di luar } \\
\text { dunia, imaginer, atau } \\
\text { khayalan }\end{array}$ & $\begin{array}{l}\text { Menyangkut tempat- } \\
\text { tempat yang nyata di } \\
\text { dunia dan relatif dekat } \\
\text { dengan wilayah cerita }\end{array}$ & Tidak terikat waktu \\
\hline 6 & Sikap terhadap cerita & Keramat & $\begin{array}{c}\text { Keramat dan sekuler } \\
\text { (keduniawian) }\end{array}$ & Sekuler (keduniawian) \\
\hline 7 & Karakter utama & Bukan manusia & Manusia & $\begin{array}{c}\text { Manusia atau bukan } \\
\text { manusia }\end{array}$ \\
\hline 8 & Tingkat kepercayaan & \multicolumn{2}{|c|}{ Fakta } & Fiksi \\
\hline
\end{tabular}

Tabel perbandingan jenis-jenis folklore mite, legenda, dan dongeng (Bascom, 1965)

Jan Harold Brunyand (dalam Dananjaja, 2002) menggolongkan legenda menjadi empat kelompok yaitu : 1) Legenda keagamaan, yang termasuk dalam legenda ini antara lain adalah legenda orang-orang suci nasrani dan legenda orang-orang saleh. 2) Legenda alam gaib, legenda semacam ini biasanya berbentuk kisah yang dianggap benar-benar terjadi dan pernah dialami seseorang. Fungsi legenda semacam ini adalah untuk meneguhkan kebenaran takhayul atau kepercayaan rakyat. 3) Legenda perseorangan adalah cerita mengenai tokohtokoh tertentu yang dianggap oleh yang empunya cerita benar-benar pernah terjadi. 4) Legenda setempat yang termasuk ke dalam golongan legenda ini adalah cerita yang 
berhubungan dengan suatu tempat, nama tempat dan bentuk topografi, yakni bentuk permukaan suatu daerah, apakah berbukit-bukit, berjurang, dan sebagainya.

Legenda Kiai adalah jenis cerita prosa naratif lisan dengan unsur tokoh seorang kiai pimpinan pesantren, sejarah budaya, masyarakat, dan benda-benda peninggalan, dan unsur magis, kekeramatan dan kepercayaan irasional. Dalam penggolongan legenda oleh Brunyand, legenda ini tergolong legenda keagamaan, perseorangan, dan setempat. Hal ini dikarenakan legenda ini memuat sekaligus kisah orang-orang suci / saleh, kisah tokoh-tokoh tertentu yang dianggap oleh yang empunya cerita benar-benar pernah terjadi, dan kisah tentang keberadaan tempat-tempat dan bangunan.

Legenda Kiai berkembang di wilayah Kota Pasuruan. Kiai adalah sosok pemuka agama di Kota Pasuruan. Pada masa hidupnya, Kiai dihormati bahkan diagungkan oleh masyarakat muslim di Kota Pasuruan. Hal ini dikarenakan Kiai dianggap memiliki karisma dan banyak dibekali karomah (mukzizat / keajaiban) oleh Allah SWT. Legenda Kiai tidak hanya berisi kisah hidup kiai sebagai tokoh agama yang suci dan saleh, melainkan pula sejarah-sejarah di balik perjalanan hidup Kiai, sejarah bangunan di sekitarnya, hubungan dengan masyarakat, dan kisah keajaiban yang dimiliki Kiai Sepuh melalui karomah yang dimilikinya. Dalam cerita yang berkembang di masyarakat, selama hidupnya Kiai diceritakan banyak memiliki atau mendatangkan keajaiban bagi masyarakat baik dalam kehidupan sehari-hari maupun dalam tujuan dakwah agama.

Legenda Kiai ini membawa serta pencitraan Kiai sebagai seorang khusus yang mendapatkan gelar kewalian dan memiliki kemampuan magis sebagai pertanda adanya karomah yang diijasahkan kepadanya. Dengan begitu, masyarakat sosial di sekitar Kiai, khususnya masyarakat pesantren, merasa perlu untuk menaruh hormat dan ketaatan pada Kiai. Dipandang dari sudut pandang sosialnya, kiai sebenarnya adalah seorang guru agama Islam sebagaimana guru agama pada umumnya. Namun karena peran sosial budayanya cukup luas, maka kiai memiliki peran yang besar bahkan mengandung pemaknaan mitologis tertentu seperti status kewalian yang memiliki kekuatan magis atau mistis (keramat). Persepsi terhadap kiai yang demikian tidak dapat dilepaskan dari penafsiran yang intersubjektif dalam dunia pondok pesantren (Romas, $2013: 2$ ).

Ahli waris, keluarga, santri, kuncen, atau masyarakat di sekitar situs makam Kiai selalu mengadakan haul yang rutin dilakukan setiap tahun dan dalam acara rebo pahingan yang diadakan sebulan sekali setiap hari rabu pahing dalam penanggalan Jawa. Dalam haul dan rebo pahingan ini, dibacakan manakib (naskah biografi ulama) yang berisikan biografi singkat, perjalanan hidup, dan karomah-karomah yang dimiliki oleh Kiai. Tidak hanya itu, 
dalam acara atau hari besar agama Islam seperi maulid nabi, Idul Adha, Idul Fitri, dan acara keagamaan yang lain yang diadakan di masjid Kiai Sepuh juga diselingi dengan pembacaan manakib.

Dalam masyarakat Kota Pasuruan, legenda Kiai banyak dituturkan dalam berbagai versi. Satu kesamaan isi cerita dari berbagai versi yang ada berkisah seputar karomah yang dimiliki oleh Kiai. Selain melalui manakib, legenda Kiai juga dituturkan melalui kegiatan mengaji anak yang seringkali diceritakan oleh ustadz, dan oleh para orang tua yang menceritakan legenda Kiai pada anak-anak untuk mengajarkan tentang agama dan kemuliaan-kemuliaan Allah SWT dan utusan-utusannya, termasuk para wali dan ulama.

Peneliti berhasil mendalami delapan lokasi situs penelitian untuk menemukan legenda / prosa naratif terkait Kiai yakni 1) kompleks makam Kiai Sepuh di Desa Gentong, 2) kompleks makam Kiai Hamid dan pesantren Salafiyah di Desa Kebonsari, 3) kompleks makam Mbah Slagah di Desa Pekuncen, 4) kompleks makam Mbah Dacin di Desa Ngemplakrejo, 5) kompleks makam Mbah Diran di Desa Bugul Lor, 6) kompleks makam Mbah Salim di Desa Pekuncen, 7) makam Mbah Mas Imam (di dalam kompleks makam Kiai Hamid) di Desa Kebonsari, dan 8) kompleks makam Mbah Thoyyib di Desa Bugul Lor. Sepuluh judul legenda telah terkumpul sebagai hasil penelitian. Judul-judul legenda tersebut adalah : 1) Kiai Sepuh dan Pedagang Nangka, 2) Kiai Sepuh dan Orang Kaya yang Ingin Membangun Masjid, 3) Doa dan Restu KH Abdul Ghofur (Kiai Sepuh), 4) Sandal Kiai Hamid, 5) Mbah Slagah dan Den Ayu Beri, 6) Kebaikan Hati Mbah Dacin, 7) Mbah Diran dan Anjingnya, 8) Mbah Salim dan Jin Sungai, 9) Kerendahan Hati dibalik Payung Mbah Mas Imam, dan 10) KH Thoyyi bin Abd. Salam, Pedagang Jamu yang Menjadi Tempat Orang Bertanya. Seluruh cerita yang terkumpul selanjutnya disusun dalam bentuk cerpen.

Cerita Kiai Sepuh dan Pedagang Nangka berisi tentang permintaan Kiai Sepuh kepada pedagang nangka untuk memberinya sebuah nangka, untuk mengingatkan agar pedagang tersebut tidak sombong. Cerita Kiai Sepuh dan Orang Kaya yang ingin Membangun Masjid berisi tentang peringata Kiai Sepuh kepada orang kaya yang berbuat riya' dan keinginannya membangun masjid dengan bantuan semua warga. Cerita Doa dan Restu KH Abdul Ghofur (Kiai Sepuh) berisi tentang terkabulnya doa Kiai Sepuh agar seseorang mendapatkan kedudukan kehormatan di mata masyarakat. Cerita Sandal Kiai Hamid berisi tentang balasan bagi orang yang dengan baik meminjamkan sandalnya kepada Kiai Hamid hingga mampu berangkat haji. Cerita Mbah Slagah dan Den Ayu Beri berisi tentang keinginan Den Ayu Beri untuk dekat dengan makam ulama (Mbah Slagah) setelah menolong Mbah Slagah dari kejaran Belanda. Cerita Kebaikan Hati Mbah Dacin berisi tentang perilaku Mbah Dacin yang 
selalu bersodaqoh setelah mendapatkan rizki atas usahanya. Cerita Mbah Diran dan Anjingnya berisi tentang Mbah Diran yang selalu bersabar meski mendapat perlakuan buruk dari orang-orang di sekitarnya. Cerita Mbah Salim dan Jin Sungai berisi tentang peran Mbah Salim dalam membantu masyarakat untuk terhindar dari gangguan Jin Sungai Gembong. Cerita Kerendahan Hati dibalik Payung Mbah Mas Imam berisi tentang perilaku unik Mbah Mas Imam yang selalu memakai payung demi terhindar dari hal buruk di sekitarnya. Cerita $\mathrm{KH}$ Thoyyi bin Abd. Salam berisi teladan KH Thoyyib yang berilmu dan menjadi tempat orang meminta jawaban/ pendapat.

\section{Tradisi Lisan Pesantren}

Seluruh cerita legenda Kiai terbentuk dalam tradisi lisan pesantren. Tradisi lisan pesantren adalah semua tradisi lisan yang tumbuh dan berkembang di kalangan pondok pesantren dan masyarakat santri. Tradisi lisan ini cukup unik dibanding dengan tradisi lisan yang lain sebab tradisi tersebut sangat berkaitan erat dengan proses pembelajaran ajaran agama Islam. Di samping itu, peranan kiai atau ustad sangat kuat untuk mempengaruhi resepsi, tanggapan atau penerimaan kaum santri terhadap tradisi tersebut secara utuh baik nilai estetik maupun pragmatiknya. Sumber utama dalam penyebaran sastra lisan ini adalah kyai atau ustadz, yang oleh kaum santri diposisikan sebagai orang yang derajatnya sangat tinggi karena mereka adalah orang-orang suci yang telah menguasai ilmu-ilmu agama (sufi). Legenda Kiai yang tergolong sebagai folklore lisan adalah sebuah sastra lisan yang hidup pada budaya lisan masyarakat pesantren. Sastra lisan pesantren ini memiliki kekuatan kepercayaan masyarakat yang sangat besar. Oleh karena itu, meskipun pada perkembangannya legenda Kyai juga banyak digunakan untuk cerita hiburan pada anakanak di luar masyarakat santri /pesantren, hadirnya tradisi sastra lisan ini pun tidak dipandang sebagai hiburan di kala senggang tetapi hadirnya tradisi tersebut merupakan bagian dari sarana pembentukan perilaku masyarakat santri yang digunakan untuk penanaman ajaran yang bersifat dogmatis. Bahkan, beberapa kelompok masyarakat memandang legenda Kyai ini sakral dan harus dipercaya sebagaimana masyarakat pesantren percaya kepada Tuhan, Allah SWT.

Penulis menyebut kepercayaan masyarakat santri terhadap kebenaran legenda Kiai sebagai kepercayaan irasional. Dalam riset sebelumnya, penulis mencatat sembilan jenis kepercayaan irasional yang ditemukan dalam legenda Kiai Sepuh. Kesembilan kepercayaan tersebut adalah : 1) Jenis kepercayaan irasional yang terbentuk akibat pandangan klasik yang 
diyakini secara umum. 2) Jenis kepercayaan irasional yang terbentuk akibat pandangan fenomena umum yang sering terjadi. 3) Jenis kepercayaan irasional yang terbentuk akibat rasa atas identitas personal. 4) Jenis kepercayaan irasional yang terbentuk akibat rasa atas identitas kelompok. 5) Jenis kepercayaan irasional yang terbentuk untuk mendukung nilai moral yang berlaku kolektif. 6) Jenis kepercayaan irasional yang terbentuk akibat pengalihan konsep kognitif. 7) Jenis kepercayaan irasional yang terbentuk akibat kesadaran pada kekuatan gaib di luar manusia. 8) Jenis kepercayaan irasional yang dibentuk sebagai wujud perintah. 9) Jenis kepercayaan irasional yang dibentuk sebagai wujud larangan (Rokhmawan \& Firmansyah,2015). Namun bukan tidak berarti, kesembilan kepercayaan irasional inilah yang akan mendukung pembentukan dan penguatan penyampaian pesan-pesan konten didaktik dalam legenda Kiai.

\section{Konten Didaktik Masyarakat Santri dalam Legenda Kiai}

Konten didaktik mencakup nilai, norma umum, dan sanksi yakni : 1) nilai baik, 2) nilai buruk, 3) norma agama, 4) norma kesusilaan, 5) norma kesopanan, 6) norma hukum, dan 7) sanksi. Konten ini terdapat di dalam cerita baik secara eksplisit maupun implisit. Konten didaktik dapat diinterpretasi dari pikiran dan perilaku tokoh, tuturan, dan interaksi antar tokoh. Nilai, norma, dan sanksi dapat dimunculkan dengan memberikan penggambaran citra baik dari tokoh sebagai model pencitraan atau sebaliknya dengan mendatangkan tokoh yang berperilaku buruk untuk selanjutnya dilabeli sebagai contoh perangai buruk yang harus dihindari.

Nilai pada dasarnya disebut sebagai standar penuntun dalam menentukan sesuatu itu baik, indah, berharga atau tidak (Fraenkel, dalam Moehadjir \& Cholisin, 1989). Secara aksiologis, nilai itu dibagi macamnya menurut kualitas nilainya, yaitu ke dalam nilai baik dan buruk. Pengertian nilai itu bersifat subyektif artinya bahwa nilai dari suatu obyek itu tergantung pada subyek yang menilainya. Dalam cerita legenda Kiai, nilai baik buruk yang terdapat di dalamnya berasal dari sudut pandang masyarakat santri.

Nilai baik dan buruk dapat diinterpretasi pada seluruh cerita yang diperoleh. masingmasing tokoh utama Kiai memiliki peran untuk menunjukkan model/ contoh praktik kebaikan. Kebaikan yang sangat menonjol pada karakterisasi tokoh ulama adalah usahanya untuk selalu menjadi pengayoman, menyampaikan doa untuk kebaikan, menjadi panutan, menjadi sumber yang sahih untuk memberikan saran dan petuah, hingga menunjukkan perilaku yang selalu ikhlas dan sabar. Gambaran nilai baik ini seringkali dibawa oleh tokoh utama yang mendukung (protagonis) penggambaran tema kebaikan. Gambaran nilai buruk 
banyak ditunjukkan oleh orang-orang yang berinteraksi secara antagonis dengan tokoh Kiai dalam cerita. Tidak semua cerita menerapkan pola penokohan protagonis-antagonis, artinya tidak semua memberikan pajanan kontras antara perbuatan tokoh baik dan buruk. Enam cerita menyajikan pola konflik antartokoh yang mempertentangkan perilaku baik dan buruk yakni cerita Kiai Sepuh dan Pedagang Nangka, Kiai Sepuh dan Orang Kaya yang Ingin Membangun Masjid, Mbah Slagah dan Den Ayu Beri, Kebaikan Hati Mbah Dacin, Mbah Diran dan Anjingnya, dan Mbah Salim dan Jin Sungai. Sedangkan empat cerita yang lain hanya memberikan pajanan perilaku baik seperti cerita Doa dan Restu KH Abdul Ghofur (Kiai Sepuh), Sandal Kiai Hamid, Kerendahan Hati dibalik Payung Mbah Mas Imam, dan KH Thoyyi bin Abd. Salam, Pedagang Jamu yang Menjadi Tempat Orang Bertanya.

Norma adalah petunjuk tingkah laku yang harus dilakukan dan tidak boleh dilakukan dalam hidup sehari-hari, berdasarkan suatu alasan (motivasi) tertentu dengan disertai sanksi. Sanksi adalah ancaman/akibat yang akan diterima apabila norma tidak dilakukan (Widjaja, 1985).

Norma agama adalah aturan-aturan hidup yang berupa perintah dan larangan, yang diyakini bersumber dari Tuhan YME. Aturan itu mengatur hubungan vertikal antara manusia dengan Tuhan (ibadah), juga hubungan horisontal antara manusia dengan sesama manusia. Norma agama terkait dengan bentuk-bentuk ajaran baik buruk dalam agama atau ajaran tertentu. Norma ini tampak secara implisit dalam tubuh cerita Kiai.

Pada cerita yang dituturkan oleh masyarakat, norma agama tercermin dari perilaku tokoh dalam cerita. Selanjutnya sambil bercerita, narasumber menyisipkan beberapa petuah norma agama sesuai dengan tema komplikasi cerita. Cerita Kiai Sepuh dan Pedagang Nangka berisi anjuran agama untuk bersodaqoh atas rizki yang diterima. Cerita Kiai Sepuh dan Orang Kaya yang Ingin Membangun Masjid berisi anjuran agama untuk tidak berbuat riya' atau beramal hanya untuk dipandang orang lain. Cerita Doa dan Restu KH Abdul Ghofur (Kiai Sepuh) dan cerita Sandal Kiai Hamid berisi anjuran agama untuk menghormati ulama, setiap doa dan restu yang disampaikannya seringkali terwujud. Mbah Slagah dan Den Ayu Beri berisi anjuran agama untuk menjalin hubungan baik dengan ulama, agar turut mendapat kebaikan. Cerita Kebaikan Hati Mbah Dacin berisi anjuran agama untuk selalu bersodaqoh membersihkan harta yang didapat dari hasil bekerja. Cerita Mbah Salim dan Jin Sungai berisi ajaran agama tentang keberadaan makhluk ghaib yang harus diimani serta diwaspadai jika menimbulkan akibat buruk bagi ummat manusia. Cerita Kerendahan Hati dibalik Payung Mbah Mas Imam mberisi anjuran agama untuk menjaga diri dari berbuat zina, salah satunya zina mata, hati, dan mulut yang biasa terjadi ketika terlalu bersosialita. Cerita KH Thoyyi bin 
Abd. Salam, Pedagang Jamu yang Menjadi Tempat Orang Bertanya menunjukkan ajaran agama tentang keberadaan ulama sebagai orang yang berilmu dan patut dijadikan tauladan serta tempat untuk memohon saran.

Norma Kesusilaan terkait dengan aturan-aturan hidup tentang tingkah laku yang baik dan buruk berasal dari hati nurani manusia. Berdasar kodrat kemanusiaannya, hati nurani setiap manusia menyimpan nilai-nilai kesusilaan. Nurani ini bersumber dari kesadaran manusia akan hak-hak asasi atas dirinya dan orang lain. Karena potensi nilai-nilai kesusilaan itu tersimpan pada hati nurani setiap manusia (yang berbudi), maka hati nurani manusia dapat disebut sebagai sumber norma kesusilaan.

Pada cerita yang dituturkan oleh masyarakat, norma kesusilaan tercermin dari perilaku tokoh dalam cerita. Perilaku tokoh menunjukkan nurani manusia untuk saling memenuhi hak asai satu sama lain. Cerita legenda Kiai mencerminkan norma kesusilaan kesadaran manusia akan hak-hak yang dibutuhkan oleh orang lain seperti hak untuk mendapatkan bantuan. Cerminan kesadaran manusia akan hak orang lain terlihat pada cerita judul cerita Kebaikan Hati Mbah Dacin dan Mbah Salim dan Jin Sungai. Kedua cerita ini berisi ajaran normatif tentang hak orang lain untuk mendapatkan bantuan. Hal pelanggaran terhadap hak dasar manusia tampak pada cerita Mbah Diran dan Anjingnya. Dalam cerita ini, tampak pelanggaran kesusilaan yang dilakukan masyarakat terhadap Mbah Diran dan anjing peliharaannya. Mbah Diran mendapat perlakuan yang tidak menyenangkan secara fisik dan verbal, serta anjing peliharaannya dibunuh.

Norma Kesopanan terkait dengan adalah aturan hidup bermasyarakat tentang tingkah laku yang baik dan tidak baik, yang berlaku dalam suatu lingkungan masyarakat atau komunitas tertentu. Norma ini biasanya bersumber dari adat istiadat, budaya, atau nilai-nilai masyarakat. Norma Kesopanan bersifat kultural dan temporal. Sanksi terhadap pelanggaran norma kesopanan adalah berupa celaan, cemoohan, atau diasingkan oleh masyarakat. Norma kesopanan yang baik muncul melalui penggambaran pribadi dan perilaku tokoh Kiai. Tokoh Kiai digambarkan sebagai pribadi yang mengedepankan kesopanan dengan menunjukkan kepedulian, pertolongan, berbagi rizki yang diperolehnya, menjaga diri untuk tidak menyakiti orang lain, menjaga diri untuk tidak berbuat buruk, dan menjadi pribadi yang berguna bagi masyarakat. Pelanggaran terhadap norma kesopanan ditunjukkan oleh beberapa tokoh yang berlawanan dengan Kiai (dalam posisi antagonis) seperti tokoh orang kaya yang tidak tahu adat berbagi rizki dalam cerita Kiai Sepuh dan tokoh warga yang melakukan perbuatan buruk dengan menghina dan membunuh anjing Mbah Diran. 
Norma hukum adalah aturan-aturan yang dibuat oleh lembaga negara yang berwenang, yang mengikat dan bersifat memaksa, demi terwujudnya ketertiban masyarakat. Norma ini bersifat memaksa dengan sanksi yang tegas. Negara berkuasa untuk memaksakan aturanaturan hukum guna dipatuhi dan terhadap orang-orang yang bertindak melawan hukum diancam hukuman. Ancaman hukuman itu dapat berupa hukuman bandan atau hukuman benda. Di samping itu masih dimungkinkan pula dijatuhkannya hukuman tambahan, yakni pencabutan hak-hak tertentu, perampasan barang-barang tertentu, dan pengumuman keputusan pengadilan. Contoh baik maupun buruk tidak tampak secara jelas dalam ceritacerita legenda Kiai. Namun jika diinterpretasi lebih dalam, beberapa hal pelanggaran norma hukum seperti perbuatan tidak menyenangkan dan penganiayaan terhadap hewan. Pelanggaran hukum pasal perbuatan tidak menyenangkan hingga terdapat unsur kekerasan dapat dikenai hukuman sesuai pasal 335 dengan hukuman paling lama 1 tahun penjara . Pelanggaran hukum pasal penganiayaan terhadap hewan hingga mati akibat kekerasan dapat dikenai hukuman sesuai pasal 302, 406, 335, 170, dan 540 KUHP dengan hukuman penjara paling lama 12 tahun penjara.

Sanksi adalah ancaman/ akibat/ konsekuensi yang akan diterima apabila norma tidak dilakukan. Sanksi atau hukuman ditetapkan sesuai dengan nilai atau norma yang dilanggar. Secara nyata tokoh-tokoh dalam cerita Kiai tidak disebutkan mendapatkan sanksi apapun. Dari seluruh cerita, sanksi terhadap pelanggar norma tidak dinyatakan, namun menjadi bahan renungan. Tokoh-tokoh yang melanggar norma diceritakan sadar dengan sendirinya akibat karomah yang dimiliki oleh para tokoh Kiai. Tokoh yang melanggar norma menyaksikan berbagai keajaiban mukzizat dan kebaikan yang yang dilakukan oleh tokoh Kiai sehingga membuat mereka sadar telah berbuat salah. Kemudian sebagai bentuk kesadaran atas kesalahan mereka, tokoh-tokoh antagonis ini kemudian memperbaiki perilaku dengan berbuat baik.

Hasil analisis pola penyajian nilai baik-buruk, norma, dan sanksi dalam cerita Kiai menunjukkan bahwa masyarakat santri memiliki cara yang bervariasi dalam menyampaikan konsep didaktik. Konsep nilai baik buruk tidak hanya diberikan dengan menunjukkan kontras dan pertentagan keduanya (baik-buruk). Masyarakat santri juga menyampaikan konsep nilai baik tanpa mempertentangkannya dengan konsep buruk. Begitulah kebaikan dapat disampaikan tanpa harus memaparkan sisi perlawanannya (buruk). Namun ketika ingin menyajikan konsep nilai yang buruk, maka perlu diimbangi dengan menyajikan konsep nilai baik. 
Konsep norma dihadirkan dengan menciptakan tokoh Kiai sebagai sosok yang menunjukkan pengamalan norma secara benar dan tokoh lawan (antagonis) yang menunjukkan pengamalan norma secara salah. Norma yang banyak dimunculkan secara nyata dan jelas adalah norma agama, kesusilaan, dan kesopanan. Sedangkan norma hukum kurang ditunjukkan.

Terkait pemberian sanksi, penggambaran sanksi dalam cerita mencerminkan pandangan masyarakat santri bahwa manusia harus terus belajar dari dalam dirinya. Masyarakat santri dituntut untuk berbuat baik dan memperbaiki diri, salah satunya dengan meneladani perilaku ulama. Mukzizat dan perlakuan baik yang ditunjukkan oleh tokoh ulama akan mampu membuat masyarakat santri sadar akan kesalahannya. Penggambaran sanksi seperti ini sering kita jumpai pula dalam cerita kisan Nabi-dan-Rasul dalam cerita ummat Islam.

\section{Cergam Legenda Kiai}

Setelah seluruh cerita Kiai yang diperoleh dalam penelitian ini sitranskripsi dalam bentuk teks tulisan, peneliti menyusun cerita dalam bentuk cergam / cerita bergambar. Cerita gambar dipilih karena peneliti ingin merevitalisasi fungsi cerita legenda Kiai sebagai alat penetapan tatanan normatif masyarakat lokal (Rokhmawan \& Firmansyah, 2015).

Legenda Kiai telah lama digunakan masyarakat Kota Pasuruan untuk menyampaikan nilai-nilai, moral, dan sanksi sosial yang berlaku secara lokal di daerahnya. Masyarakat santri Kota Pasuruan memiliki seperangkat nilai, moral, dan sanksi adat yang dikembangkan dari ajaran agama Islam. Ajaran lokal ini sampaikan secara turun-temurun melalui budaya lisan bercerita legenda Kiai. Dalam buday lisan masyarakat, legenda Kiai disampaikan melalui berbagai kesempatan seperti ketika mengaji atau pada perhelatan acara keagamaan. Ddalam cakupan yang lebih sempit di lingkungan keluarga, legenda Kiai disampaikan oleh orang tua untuk memberikan nasihat petuah kepada anak mereka, misalnya menjelang tidur atau setelah sholat berjamaah. Budaya baik ini tentu harus dilestarikan. Problem yang muncul adalah hilangnya kesadaran atas petingnya menyampaikan legenda serta mulai berkurangnya penutur cerita akibat ketidaktahuan akan cerita-cerita legenda tersebut. Untuk itu peneliti menawarkan bentuk cerita bergambar untuk yang ditulis sekaligus menyimpan bentuk cerita legenda Kiai.

Cerita bergambar adalah bentuk cerita singkat (cerpen) dengan genre cerita anak, yang dilengkapi gambar sebagai bahan ilustrasi. Genre cerita anak memiliki ciri khas khusus di antaranya dalam hal penetapan topik atau tema cerita, pengondisian tokoh, penggambaran latar, pembentukan suasana, serta penyajian bahasa dalam mengembangkan barasi dan 
dialog. Genre cerita anak cenderung mengutamakan kosep yang konkret untuk disajikan ke hadapan anak-anak, dengan pertimbangan bahwa konsep yang konkret akan mudah dipahami oleh anak (Nurgiyantoro, 2010 ; Sutherland \& Arbuthnot, 1991 ; Sarumpaet, 2010).

Topik atau tema yang diberikan adalah seputar kehidupan sehari-hari, konten / pesan didaktik yang disampaikan juga seputar perilaku yang layak untuk ditiru secara mudah dan sederhana seperti : berbagi, gotong royong, atau menolong orang lain yang mengalami kesulitan. Melalui topik seperti ini anak diajak untuk membedakan nilai baik dan buruk secara konkret. Tokoh dalam genre cerita anak dapat berupa tokoh konkret (seperti manusia dan hewan) maupun fantasi (makhluk astral, setan, peri, atau malaikat). Karakterisasi tokoh dalam cerita anak tidak mendalam dan cenderung penuh aksi, dengan ini diharapkan anak dengan mudah mampu mengimajinasikan sosok tokoh serta menarik untuk diikuti lakuannya. Pendeskripsian latar dan suasana yang dikembangkan dapat bersifat konkret / nyata maupun abstrak / khayalan, namun masih ringan untuk diimajinasikan oleh anak-anak. Oleh karenanya penggambaran latar dan setting cerita pun tidak terlalu spesifik. Dalam menyajikan bahasa, kemampuan berbahasa anak-anak masih terbatas dalam hal kosakata, panjang kalimat (dibuktikan dengan hasil pengukuran rata-rata kemampuan berujar / Mean Lenght Utterance / MLU), dan panjang wacana. Dalam hal kosakata, anak-anak tentu kesulitan untuk memahami ragam istilah asing, ilmiah, keilmuan, diksi dengan konsep rumit (misanya kata :/mengabdi/), atau bentuk leksem yang kompleks (kata berimbuhan, berulang, dan majemuk). Dalam hal panjang kalimat, anak-anak terbatas pada kemampuan memahami kalimat dengan panjang rata-rata lima sampai tujuh kata (Dardjowidjojo, 2003). Oleh karenanya dalam menuliskan narasi dan dialog, penulis perlu membatasi bahasa sesuai dengan kemampuan berbahasa pada anak-anak.

Produk Cergam dikembangkan dengan menganut struktur prosa naratif. Cergam disusun dengan struktur generik lengkap : abstrak, orientasi, komplikasi, evaluasi, resolusi, dan koda (Anderson \& Anderson, 1997). Penulis memanfaatkan bagian abstrak untuk memperkuat unsur pesan didaktik melalui penyampaian dasar ajaran agama yang akan dibahas dalam cerita. Bagian orientasi berisi deskripsi tokoh dan latar. Komplikasi berisi rentetan peristiwa yang mengisi jalan cerita dan konflik antar tokoh. Evaluasi berisi penegasan ulang setiap peristiwa untuk tujuan memperjelas isi cerita. Resolusi berisi penetapak penyelesaian dari permasalahan di dalam cerita. Koda berisi penutup cerita berupa refleksi dan penetapan nilai-moral yang dapat diteladani oleh pembaca (anak-anak).

Cergam dilengkapi dengan ilustrasi cerita. Ilustrasi yang digunakan adalah ilustrasi anak bergenre kartun berwarna. Pewarnaan menggunakan pewarnaan digital RGB (Red- 
Green-Blue). RGB juga disebut dengan warna additive atau warna pencahayaan dengan karakter cerah, segar, dan menyenangkan, cocok untuk anak-anak. Font pada balon percakapan menggunakan font Arial Rounded MT Bold. Secara keseluruhan pengerjaan gambar dilakukan secara digital memanfaatkan software Adobe Photoshop CS 6. Cerita dikemas dalam bentuk buku cerita bergambar untuk anak-anak dengan dimensi landscape berukuran $13 \times 19 \mathrm{~cm}$ sesuai dengan standar buku cerita anak pada umumnya.

\section{Penutup}

Cerita legenda Kiai terbukti ada dalam kehidupan masyarakat Kota Pasuruan. Cerita ini berkembang dan dilisankan dari generasi-ke-generasi. Selama ini cerita legenda Kiai dilisankan dalam kehidupan tradisi masyarakat Kota Pasuruan, dalam kehidupan sehari-hari hingga dalam acara-acara adat dan keagamaan. Namun sayangnya budaya lisan ini mulai hilang. Ketertarikan masyarakat terhadap bentuk budaya lisan ini mulai hilang hingga menyebabkan semakin berkurangnya kuantitas penutur dan intensitas penuturan cerita. Jika dibiarkan maka pada masa yang akan datang cerita legenda Kiai ini akan hilang.

Peneliti telah berhasil menelusuri dan mentranskripsi sepuluh judul cerita legenda Kiai dari delapan lokasi penelitian yang rata-rata merupakan situs makam Kiai. Kesepuluh judul cerita tersebut adalah : 1) Kiai Sepuh dan Pedagang Nangka, 2) Kiai Sepuh dan Orang Kaya yang Ingin Membangun Masjid, 3) Doa dan Restu KH Abdul Ghofur (Kiai Sepuh), 4) Sandal Kiai Hamid, 5) Mbah Slagah dan Den Ayu Beri, 6) Kebaikan Hati Mbah Dacin, 7) Mbah Diran dan Anjingnya, 8) Mbah Salim dan Jin Sungai, 9) Kerendahan Hati dibalik Payung Mbah Mas Imam, dan 10) KH Thoyyi bin Abd. Salam, Pedagang Jamu yang Menjadi Tempat Orang Bertanya.

Kesepuluh cerita ini terbukti menjadi pembawa (carrier) konten didaktik, yakni konten yang mengajarkan tentang nilai, norma, dan sanksi yang ditetapkan dalam adat dan kebudayaan masyarakat Kota Pasuruan. Konten didaktik dalam legenda Kiai mencerminkan pandangan hidup masyarakat santri di Kota Pasuruan. Masyarakat santri menetapkan tokoh Kiai sebagai panutan dalam menentukan perilaku baik-buruk dan pengamalan norma-norma secara baik. Pemberian sanksi tidak ditunjukkan secara langsung dalam cerita melainkan menjadi perenungan masyarakat. Sanksi sebaiknya tidak perlu diberikan jika orang yang bersalah dapat disadarkan dan mau memperbaiki perilakunya. Begitulah pandangan masyarakat santri tentang pranata sosial yang mereka ‘titipkan' dalam cerita legenda Kiai.

Sebagai bentuk produk yang nyata, penulis telah 'mengawetkan' cerita legenda Kiai dalam bentuk cergam. Tidak hanya berfungsi sebagai wahana penyimpanan cerita, cergam 
juga akan mampu mendongkrak minat masyarakat khusunya generasi anak-anak untuk terus menggenal dan menuturkan cerota-cerita legenda Kiai di sekitarnya.

\section{Daftar Rujukan}

Anderson, Mark dan Kathryn Anderson. 1997. Text Types in English Vol. 1-3. Australia : Macmillan Education.

Bascom, W. 1954. Four Function of Folklore. The Journal of American Folklore. Vol 67 No. 266, 333-349.

Bascom, W. 1965. The Form of Folklore : Prose Narrative. The Journal of American Folklore, Vol. 78 No. 307 , 3-20.

Dananjaja, J. 2002. Folklore Indonesia : Ilmu Gosip, Dongeng, dan Lainlain. Jakarta:

Dardjowidjojo, Soendjono. 2003. Psikolinguistik : Pengantar Pemahaman Bahasa Manusia. Jakarta : Yayasan Obor.

David, D., Lynn, S. J., \& Ellis, A. 2009. Rational and Irrational Beliefs: Research, Theory, and Clinical Practice. Oxford University Pers.

Dharmojo. 1998. Sastra Lisan Ekagi. Jakarta: Pusat Pembinaan dan Pengembangan Bahasa Departemen P \& K.

Geertz,Clifford. 1960. The Religion of Java. Chicago: The University of Chicago

Geertz,Clifford. 1981. Abangan, Santri, Priyayi Dalam Masyarakat Jawa.Terjemahan oleh Aswab Mahasin. Jakarta: Pustaka Jaya.

Haviland, W. A. 1985. Antropologi. Jakarta: Erlangga.

Lantini, E. S. 1996. Refleksi Nilai-nilai Budaya Jawa Dalam Serat Suryaraja.Jakarta: Depdikbud.

Nurgiyantoro, Burhan. 2010. Sastra Anak : Pengantar Pemahaman Dunia Anak. Yogyakarta : Gadjah Mada University Press.

Peursen, C. A. 1988. Strategi Kebudayaan. Yogyakarta: Kanisius.

Pustaka Utama Grafiti.

Rokhmawan, Tristan dan Bayu Firmansyah. 2015. Bangunan "Kerajaan Surgawi": Kepercayaan Irasional dan Fungsi Sosial dalam Legenda Kiai Sepuh. Jurnal Ilmu-ilmu Humaniora. No. 1 Edisi 2015. Jember : FIB Universitas Jember.

Rokhmawan, Tristan. 2016. Mengakrabkan Budaya Lisan dan Penyelenggara Pendidikan sebagai Upaya Merevitasilasi Kesusastraan Lisan-Lokal. Prosiding Seminar Nasional Bahasa dan Sastra Indonesia - Nitisastra 1. Malang: Pascasarjana Universitas Negeri Malang.

Romas, C. S. 2013. Kekerasan di Kerajaan Surgawi. Yogyakarta: LKPM.

Sarapik, V. 2000. Artist and Myth. Electronic Journal of Folklore, Folklore Vol. 15 by the Folk Belief and Media Group of ELM .

Sarumpaet, Riris Toha. 2010. Pedoman Penelitian Sastra Anak. Jakarta : Raja Grafindo Persada.

Soedjijono. 2002. Legenda Pulau Bawean (Kajian dengan Pendekatan Arketipal). Prosiding Seminar Akademik, (p. Volume 2).

Soenarjati, Moehadjir dan Cholisin. 1989. Konsep Dasar Pendidikan Moral Pancasila. Yogyakarta : IKIP Yogyakarta.

Spradley, J. P. 1997. Metode Etnografi. Yogyakarta: Tiara Wacana. 
Sutherland \& Arbuthnot, 1991

Wellek, R., \& Warren, A. 1990. Teori Kesusastraan. Jakarta: Gramedia.

Widjaja, A.W. 1985. Kesadaran Hukum Manusia dan Masyarakat Pasncasila. Jakarta : Era Swasta. 